\title{
Comparison of Chinese and English Education
}

\author{
Jiarui Yang* \\ School of No.1 High School, 053099, Hengshui City, Hebei Province, China \\ *Corresponding author. Email: 2006030430@st.btbu.edu.cn
}

\begin{abstract}
China has a long history of education. The education system has gradually improved, and Britain is a typical representative of western educators, with a more advanced education system. With the increase in the number of people going abroad, it is necessary to consider why many Chinese students want to study abroad. Therefore, in this article, it is important to compare the two educational systems. This paper analyzes the education system in China. One of the fascinating aspects of the Chinese education system is the emphasis on traditional knowledge, which provides students with a solid foundation. Children in our country should learn more in childhood. But western students are slow to learn. Innovation and creativity are the biggest differences between education systems. Sometimes, Chinese education limits students' creativity. This paper is divided into three parts: The first part compares Chinese and British education systems. It includes the Chinese education system and the British education system. Both have advantages and disadvantages. Chapter two is about higher education. It is divided into two parts: the Chinese higher education system and the British higher education system. The third part is the comparison between Chinese and British classroom discipline.
\end{abstract}

Keywords: Education System, Innovation, Independence, Classroom Discipline.

\section{INTRODUCTION}

In a broad sense, education refers to any action or experience that shapes an individual's mind, character, or physical abilities. In the technical sense, education is the process by which society intentionally transmits its cultural heritage -- the knowledge, values, and skills it has accumulated -- from one generation to another through schools, colleges, universities, and other institutions.

The People's Republic of China has a national public education system, including primary and secondary schools (upper and lower) and universities. Strictly speaking, nine-year education is compulsory for all Chinese students.

In the United Kingdom, education is a devolved matter because each country in the United Kingdom has its own system under its own government. The UK government is responsible for education in England, led by the Secretary for Children, Schools and Families and the Secretary for Innovation, Universities and Skills. However, the day-to-day management and funding of state schools is the responsibility of local education authorities.
There are many differences between educational systems, which are caused by many reasons, such as cultural differences, economic reasons, concepts, etc.

\section{THE COMPARISON OF EDUCATION SYSTEM IN CHINA AND BRITSH}

China's education has a long history. The education system is handed down from generation to generation. However, the most successful period has been since the 1960 s, that is, after the founding of new China, especially the period of adapting to economic modernization. After Mao Zedong, the leadership of the Communist Party of China took education as the basis of the Four Modernizations.

\subsection{Chinese Education System}

Nowadays, quality education has attracted people's attention with its unique importance. The goal of quality education should be to improve the three special qualities of students: the quality of workers, the country, and the nation. Quality education has four aspects: morality, intelligence, sports and labor.

In addition, we must realize three major changes in the long process, that is, from simply cultivating top 
minority students to improving collective quality, from simply emphasizing intellectual education to all-round development to morality, weathering, aesthetics, and labor, and from examination education to socialist modernization education [1]. All these reflect the urgent adaptation to the challenging competition in the current society. Therefore, quality education can be regarded as the "biggest leap" in the reform of the education system.

In China, education has always been an important part of people's life. Education is divided into three categories: basic education, higher education, and adult education. The compulsory education law stipulates that every child has nine years of formal education [2]. Students enter primary schools, secondary schools, colleges, and universities and then obtain degrees. Although China has a great civilization from the old to the present, its education system is not as perfect as we expected. Students learn English, Chinese and mathematics as their main courses and then learn biology, geography, history, politics, physics, chemistry, and physical education. Students' courses are not as interesting as those in Britain and the United States.

Many schools strictly manage the whole student. In addition, many teachers are serious and responsible. Students concentrate on the classroom and have profound knowledge, which is closely related to the success of the Olympic Games.

China's education system is more flawed [3]. First, there is a lack of cultivation of students' innovative consciousness. The reason is that China is taking the form of exam-oriented education. Creative thinking, such as tentative guess, adventure assumption and intuition, inspiration and other thinking modes, is important to breakthrough general thinking. Rapid advances in technology require encyclopedic knowledge and unconventional ways of thinking. So, it can turn knowledge into a foundation for creativity. Students need to be creative in society after graduation. School teachers emphasize book knowledge, advocate rote memorization, use standard answers, do a lot of practice, resulting in the inhibition of personality development. This is a common phenomenon. So many students feel tired or even bored when they learn knowledge. As a result, creativity is fading from people's minds day by day. In other words, Chinese students are not born without a sense of innovation. But it is disappearing under the influence of environmental influences.

Although the situation has improved since the country implemented quality education, there is still some dissatisfaction. According to the survey, 80 per cent of students think quality education is ineffective. They still think that rural education does not develop students' abilities. Students also have some heavy burdens. If a suitable environment provides space for students' curiosity, it will increase students' awareness of innovation.
Another drawback of the Chinese education system is that it fails to develop other abilities. Many students know this knowledge, but they don't know how to practice it.

\subsection{British Education System}

In British, the purpose of schools is to provide children with literacy and other basic skills [4]. They will need to be active members of society and participate in its activities. In Britain, a man's career determines his future. Where you get your education still matters in your life. The actual decisions are made by local education authorities, while the central government sets broad education policy guidelines and provides funding. Some children go to private schools run by private organizations, for which their parents pay. Some went to public schools, such as Eton and Harrow. Younger children can attend private preparatory schools until the age of 13. Some parents may send their children to private schools, even if it violates their principles because they think their children will receive a better education. All children must study English, maths, science, religious education, history, geography, technology, music, art, physical education and modern languages. Education in Britain is now compulsory.

This system has many advantages. British teachers cultivate creativity and fill students' minds with questions rather than theorems. Students think for themselves instead of following the teacher's way. The teacher asked the students to find the answer for themselves. Sometimes, the teacher will give some appropriate suggestions, but not all of them. So, if students are at home or some other place, they can solve problems independently instead of at school. The system benefits students a lot by helping them think like scientists and make breakthroughs. As the saying goes: "Teach a man to fish is better than teach a man to fish." Westerners use it effectively in education.

To sum up, British students live independently, have creative and innovative thinking, and are fully prepared for entering society [5].

However, this system also has its own problems. Students show lax discipline in class because the school does not take a serious attitude towards students, resulting in students not being as diligent as Chinese students. Therefore, the juvenile crime rate is higher than that in China.

\section{THE HIGHER EDUCATION}

Higher education reflects the political policy changes that have taken place in contemporary China. In general, when universities reopened in the early 1970s, enrollment was reduced from pre-Cultural Revolution levels, and enrollment was limited to those 
recommended by their work units for good political credentials and who excelled in manual labor. In a 1975 letter to MAO Zedong, Deng Xiaoping reportedly said that graduates left university "unable to read a single book in their field of study." In addition, university faculty and administrators are demoralized by the situation they faced.

\subsection{The Higher Education in China}

Efforts to improve the quality of education in 1975 were unsuccessful. It seems doubtful that, by 1980, politically oriented standards had even succeeded in increasing the number of migrant children enrolled. Successful university candidates are often the children of cadres and officials who use personal connections to "get in" by the back door. Students from families of officials will accept the requirements to work in the countryside for at least two years, usually in the suburbs, so they can keep their distance from their families. Village officials, eager to ingratiate themselves with their parents, are happy to recommend these young people to university after satisfying their working conditions.

The commitment to the four modernizations requires great advances in science and technology. Under the modernization plan, higher education will become the cornerstone of training and research [6]. Since modernization depends on greatly increasing and improving the ability training of scientists and engineers, a breakthrough is needed. A renewed focus on higher education and academic quality, in which science is the four modernizations that will play a central role, emphasizing the need for scientific research and training. Such concerns date back to the Cultural Revolution when higher education was shut down, leading to severe staffing shortages and quality deficiencies in science. To meet the need for scientific training, in September 1986, the Sixth Plenary Session of the 12th CPC Central Committee has adopted a resolution on the Guiding ideology for building a Socialist Society, emphasizing the importance of education and science.

However, reformers realized that the higher education system was far from being modernized and needed more reform. In 1986, The State Council promulgated the Interim Regulations on the Administration of Institutions of Higher Learning, which has made great changes in the administration and adjusted the opportunities, directions and contents of education [7]. With the increased independence afforded by educational reforms, universities and colleges can choose their own program of instruction and courses. Here are some examples: To accept or cooperate with other socialist institutions to form a "consortium" of scientific research and technological development projects in teaching, scientific research and production; To recommend the appointment or removal of the vice president and other staff members; To be responsible for the allocation of capital construction investment and funds allocated by the state, and be responsible for using its own funds to carry out international exchange activities [8].

The changes also allow universities to accept financial aid from work units and decide how to spend it without asking education authorities for much money. In addition, higher education institutions and work units can sign contracts to train students.

Higher education institutions have also been given a greater role in opening schools across regions and sectors. Within state-approved budgets, universities are given greater freedom to allocate funds as they see fit, using income from tuition, technology and consulting services for their own development, including collective benefits and bonuses.

\subsection{The Higher Education in the UK}

The higher education system in the UK can be regarded as one of the top areas in the world [9]. It has its merits: (1) it is profession-oriented. The universities realize that helping students find jobs is one of the functions. So, the courses in the college have a close relationship with society. None of the courses are useless. The managers in the universities know that the rate of taking up an occupation influences the development and future of the universities. For example, The University of London, in these years from a college, is a super university because of the high employment rate.

(2) Universities keep up with The Times. Students have no set textbook. Instead, various books in libraries are becoming textbooks. The teacher determines all the content that the students must learn. Therefore, teachers will go for something novel, especially something that will increase employment.

(3) Great ability. There are few exams, but students have to do a lot of assignments and presentations, which help improve their expressions and creativity. Sometimes there is no right answer to a question. The teacher encouraged his students to think. This helps students to master the knowledge better.

(4) High-quality supervision system. If parents are not satisfied with the teacher's evaluation system or curriculum content, they can ask the school to investigate the statement. If this is true, after five times, the teacher will lose his or her job. Teachers can't get back at parents, and they can't get back at students. Otherwise, they will become notorious from now on. No school would accept them.

(5) Equality between students and teachers. The status of teachers is not as high as in China. Students always go by first names instead of last names. Teachers 
are worried that students won't ask them questions. If this happens, the teacher will lose his or her job. The British believe that teachers should teach students because the students pay them. Thus, students do not have to appreciate it because it is an equivalent change. But students should not take up the teacher's private time.

(6) Courses are more advanced but not very popular. They want to know that a person can do everything well. Therefore, it is important to strengthen the difficulty of the course. This will give them a good or well-paid job. This kind of education system attracts many Chinese students to study abroad, especially for short, guaranteed master's degrees.

\section{A COMPARISON OF CLASSROOM DISCIPLINE MANAGEMENT BETWEEN CHINA AND BRITAIN}

Classroom discipline management is the most basic factor in classroom management. It is an organic part of teaching work to create the best teaching environment by maintaining classroom discipline to improve classroom teaching efficiency and ensure the smooth progress of classroom teaching activities [10]. In Chinese schools, classroom discipline refers to formulating and implementing classroom behavior codes and norms to deal with students' problem behaviors and other activities. It is the main basis for teachers to manage, evaluate and guide students' classroom behaviors [11]. Classroom discipline is also a part of classroom management in British schools, but it is not managed by making uniform rules. Instead, it is formed according to the ideas of different schools, and teachers pass the rules to learners in different ways [12]

\subsection{The Chinese class}

The classroom rules are the prerequisite for the formation of good classroom discipline and must be carefully formulated. Chinese schools will establish rules and regulations and clearly write rules. For example, in The Code of Conduct for Primary and Secondary School Students [13], "Strictly observe the discipline in class and consciously maintain the class order. Obey the management of teachers and students on duty; Class to sit upright, facing the platform, keep quiet, not casually talk, not allowed to doze off, not allowed to leave the seat without permission; It is strictly prohibited to heckle and intentionally make noise and other small movements; No books or periodicals unrelated to the lecture." It can be seen that the code of conduct mostly adopts imperative sentences, which are mandatory and require learners to obey in the form of commands and prohibitions. The rule making mainly follows the principle of listening. In contrast, other discipline management rules are based on the auxiliary listening principle, which is also formed according to the "teacher-centered" characteristics of the Chinese classroom.

In China, the implementation of classroom rules in schools is straightforward and strict. The teacher told the learners all the rules to follow in the first lesson. For example, if students want to ask or answer a question, they must raise their right hand and sit up straight. Sometimes, individual students forget the rules. Unless they can remember the rules clearly, the teacher will ignore their requirements. Finally, the whole class can follow the rules. Teachers will adopt a class committee system to manage classroom discipline. Usually, on the blackboard at the back of the classroom, there were small red flowers next to the students' names. The teachers would have the disciplinary committee record each student's performance. Red flowers would be added for good behavior, and red flowers would be deducted for bad behavior. If the punishment fails, parents will be invited to the school for communication, and the school and family will jointly educate the students. Teachers adopt the management system of the class committee, which is similar to small interpersonal social relations, to reduce the burden of teachers and improve work efficiency. At the same time, learners can learn basic management skills and improve their communication skills. And through the reward and punishment system displayed publicly, the competition consciousness among learners is encouraged to achieve the effect of reward and punishment.

\subsection{The British Class}

In British schools, classroom discipline is to respect teachers, classmates and the school, which belongs to the category of morality. Still, morality is infected, not taught, so British schools do not make uniform rules of classroom discipline. At the same time, learners enjoy the right of freedom, and they can do what they want to do within a certain scope. As long as the behavior does not interfere with the class too much, it will not be stopped. In British school classes, especially primary school classes, it is not difficult to see that learners walk around freely in the classroom, answer questions spontaneously without raising their hands, and some students directly run to the teacher to ask their doubts. The main principle of rulemaking is comfort and security building, in contrast to China, which is based on British classrooms" "student-centred" nature.

In British schools, students are encouraged to be individuals. Teachers give students autonomy to control what they say and do in class through indirect means. There is no doubt that there is too much noise at the beginning of every class. When a fourth-grade teacher at a British primary school claps her hands a few times rhythmically at first, the students respond by clapping their hands in the same rhythm, stopping talking and 
sitting down. This behavior is designed by the teacher and the result of repeated trainings. In the early stages, only a few students unconsciously imitate. The teacher will deliberately praise these students, and the other students who want to be praised will applaud back. Gradually, the class has succeeded in learning this pattern of behavior. British school teachers do not teach rules directly in the classroom, and they make rules through training based on behaviorist theory [14]. In the end, learners learn how to manage themselves in the classroom through this training method, and do not have a sense of pressure, and subtly improve their self-control within their comfort zone.

As mentioned above, both Chinese and English schools have rules for classroom discipline, while Chinese schools have rules that directly govern learners' behavior in the classroom. Learners must have compliance to ensure the smooth implementation of this management mode; otherwise, targeted disciplinary measures are needed to avoid the failure of this management mode. British schools preserve as much freedom as possible for learners, establish a sense of security and indirectly manage classroom discipline. Learners must form a sense of respect, with moral constraints, to have the ability of self-management to ensure good classroom discipline.

\section{CONCLUSION}

There are big differences between China and Britain from the perspectives of schooling, teaching methods and priorities. The education systems of the two countries have both advantages and disadvantages. As a result, it is difficult to judge which is better just by the admission rate. Therefore, it is more sensible to estimate the number of elites that the system contributes to society. Britain has won more Nobel Prizes than any other country, and its education system is considered one of the most important factors. Generally speaking, Chinese universities pay attention to classroom education, mainly indoctrinate "exam-oriented education", and college education is "strict in and lenient out"; British universities pay attention to comprehensive training, mainly independent "ability education", and college education is "wide in and strict out".

China and Britain are the birthplaces of Oriental civilization and the important town of western culture. The existence of differences is inevitable. There are differences, but the key is that how to treat them appropriately. The Chinese and British higher education systems have their own advantages and disadvantages and their own characteristics. It is hoped that Chinese education can learn from each other's strengths and make up for their weaknesses according to the actual situation, so that the teaching ideas, teaching means and teaching methods of colleges and universities in China can further meet the requirements and pace of the development of the times.

\section{REFERENCES}

[1] Q.J. Guo, \& X. Lei. (1995). Educational Law of the People's Republic of China. Beijing Broadcasting Institute Press.

[2] The Provisional Regulations New (2018), Compulsory education Law.

[3] Y. Jiang. (2005). Analysis of higher Education System reform: from the perspective of neo-liberal Theoretical Trend of thought. (Suzhou University)

[4] J.J. Feng. (1998). Change and Development trend of Western Educational Research Paradigm. Research in Education (01), 26-30.

[5] C.X. Wang, B. Zhu, M.Y. Gu (1982). Comparative education. Beijing: People's education press.

[6] Y. Jiang. (2005). Analysis of higher Education System reform: from the perspective of neo-liberal Theoretical Trend of thought. (Suzhou University)

[7] The Provisional Regulations, the Management of Institutions of Higher Learning, 1986

[8] Z.F. He. (2001). Gifted education and characteristics. Hunan Daily.

[9] S.X. Liu, \& Zhang Yingqiang. (2007). Higher Education Reform. Shanghai Jiao Tong University Press.

[10] Y. Hu. (2009). Educational Psychology. East China Normal University Press.

[11] J.X. Xin. (2009). Classroom Teaching Management Strategies. Beijing Normal University Press.

[12] UKEssays. Classroom Management: An introduction [EB/OL]. 2018-11 [2020-2-2]. https://www.ukessays.com/essays/education/introd uction-to-classroom-management-educationessay.php?vref $=1>$.

[13] Ministry of Education. Rules for Primary and Secondary School Students [EB/OL]. 2015-8-20 [2020-2-2]. http://www.moe.gov.cn/srcsite/A06/s3325/201508/ t20150827 203482.html.

[14] Wagstaff, J. (2012). Classroom behaviour, 3rd ed. by Bill Rogers. Emotional and Behavioural Difficulties, 17(2), p.216. 